\title{
Maciej Bukowicki
}

\section{NIEPODLEGKOŚĆ I CO DALEJ?}

Niepodległość zdefiniować można jako „władzę pierwotną, trwałą, niezależną w stosunkach wewnętrznych i zewnętrznych oraz prawnie nieograniczoną" '. Często używa się też pojęć suwerenność lub niezależność. Każde z nich sprowadza się w istocie do stanu, w którym dane państwo może na swoim terytorium w sposób nieskrępowany stanowić i egzekwować prawo. Należy jednak zastanowić się - czy niepodległość jest celem samym w sobie? Odpowiedź na to pytanie stanie się pretekstem do dalszych rozważań zawartych w tej pracy.

Warto zauważyć, że suwerenność (pojęć „suwerenność” i „niepodległość” będę używał tutaj wymiennie) to przymiot państwa. Powinniśmy teraz zadać kolejne pytanie - w jaki sposób możemy scharakteryzować państwo? W doktrynie prawniczej przyjmuje się, że „państwo jest polityczną, hierarchiczną, przymusową, terytorialną i suwerenną organizacją obejmującą całe społeczeństwo"2. Z tej definicji można wyodrębnić trzy elementy składowe państwa: ludność, terytorium, suwerenną władzę (chociaż obecnie coraz częściej dodaje się również uznanie międzynarodowe jako czwarty podstawowy przymiot państwa ${ }^{3}$ ). Widzimy wyraźnie, że suwerenna władza to tylko jeden $z$ trzech równie ważnych elementów. Do powstania państwa niezbędne są terytorium, na którym mogłoby ono funkcjonować oraz ludność - wspólnota narodowa.

Jednak słowa „ludność” i „naród” to hipostazy. Ujmując rzecz bezpośrednio, trzeba powiedzieć, że państwo tworzą ludzie. W jakim celu? Na to pytanie odpowiedzi już w XVI wieku dostarczył Jan Zamoyski, wyjaśniając, że państwo jest po to, „byśmy wolności naszych zażywali”. Wracając więc do postawionego wyżej pytania, można stwierdzić, iż niepodległość nie jest celem samym w sobie, lecz jedynie środkiem, a celem właściwym pozostaje wolność. Suwerenność to narzędzie w rękach państwa (dokładniej władzy państwowej), która za jego pomocą

${ }^{1}$ B. Banaszak, Prawo Konstytucyjne, Warszawa 2015, s. 216.

${ }^{2}$ T. Chauvin, T. Stawecki, P. Winczorek, Wstęp do prawoznawstwa, Warszawa 2016, s. 62.

${ }^{3}$ Por. R. Bierzanek, J. Symonides, Prawo międzynarodowe publiczne, Warszawa 2015, s. $120-123$. 
ma stwarzać odpowiednie warunki dla społecznego, gospodarczego oraz kulturowego rozwoju narodu (obywateli).

Z powyższych rozważań wynika, że niepodległość stanowi jedynie początek drogi do zbudowania silnego, trwałego, rozwiniętego państwa. Dlatego tak ważne jest pytanie o ustrój państwa, a więc o to, w jaki sposób wykorzystać niepodległość, żeby osiągnąć wszystkie wskazane wyżej cele. Oczywiście, pełna odpowiedź wykracza poza założenia tej pracy. Niemniej jednak, można wskazać płaszczyznę aksjologiczną, na której powinien opierać się ustrój państwowy. Takiego fundamentalnego zespołu wartości dostarcza prawo naturalne. Wskażę zatem i omówię teraz trzy najbardziej elementarne spośród nich: życie, wolność i własność.

\section{Prawo naturalne}

Konsekwentnie zacząć należy od pytania, czym jest prawo naturalne?

Prawo naturalne to najogólniej, zespół norm, które nie są wytworem ludzkiego stanowienia. Istnieją one w sposób obiektywny i obowiązują niezależnie od prawa pozytywnego oraz są możliwe do poznania przy pomocy ludzkiego rozumu4. Koncepcje prawnonaturalne były obecne już w filozofii greckich sofistów. W średniowieczu ich rozwój dokonywał się za pośrednictwem św. Augustyna i św. Tomasza z Akwinu. W kolejnych wiekach temat ten podejmowali tacy filozofowie i prawnicy jak Hugo Grocjusz, John Locke czy Immanuel Kant. Bezpośrednie odwołania do prawa naturalnego znajdujemy także w amerykańskiej Deklaracji Niepodległości z 1776 roku i francuskiej Deklaracji Praw Człowieka i Obywatela z 1789 roku. Wyparte przez pozytywizm prawniczy, swoje odrodzenie przeżyły po drugiej wojnie światowej. Doświadczenie okrucieństw XX wieku skłoniło przywódców politycznych oraz teoretyków prawa do podania w wątpliwość gwarancji prawa pozytywnego. Dlatego postanowiono poddać prawa natury procesowi pozytywizacji, czego owocami były przede wszystkim Powszechna Deklaracja Praw Człowieka ONZ z 1948 roku i Europejska Konwencja o Ochronie Praw Człowieka i Podstawowych Wolności z 1950 roku.

Warto zauważyć, że współcześnie akceptuje się niewiedzę odnośnie epistemologii praw naturalnych. Ich pochodzenie - jakkolwiek cały czas pozostaje przedmiotem akademickiej dyskusji - jest indyferentne względem ich obowiązywania. Ponadto, przyznaje się im aprioryczny charakter. Zwrócić też należy uwagę na nazewnictwo pierwszego z wymienionych powyżej aktów prawa międzynarodowego. Został on nazwany deklaracją, a nie na przykład konstytucją. Twórcy Po-

${ }^{4}$ Por. Leksykon współczesnej teorii i filozofii prawa, pod red. J Zajadło, Warszawa 2017, s. $250-254$. 
wszechnej Deklaracji Praw Człowieka z 1948 r. wyrazili tym samym przekonanie, że nie konstytuują niczego nowego, a jedynie dekretują to, co już istnieje. Prawo naturalne zostało poddane pozytywizacji na gruncie prawa międzynarodowego, jednak nadal utrzymuje swój autonomiczny charakter i w swojej istocie jest odwieczne i uniwersalne.

Historia filozofii wskazuje wiele źródeł poznania praw naturalnych: odwieczne prawo natury przenikające wszystko (filozofia grecka), nakazy Boga (filozofia oraz teologia chrześcijańska), imperatyw ludzkiego rozumu (Immanuel Kant). W doktrynie katolickiej prawo naturalne pojmowane jest jako prawo „zapisane i wyryte w duszy każdego człowieka”" . Katechizm Kościoła Katolickiego definiuje prawo naturalne następująco:

Prawo naturalne, obecne w sercu każdego człowieka i ustanowione przez rozum, jest uniwersalne w swoich przepisach i jego władza rozciąga się na wszystkich ludzi. Wyraża ono godność osoby i określa podstawę jej fundamentalnych praw i obowiązków. ${ }^{6}$

\section{Życie}

Uciekając się do mądrości starożytnych, można powtórzyć za Rzymianami clara non sunt interpretanda. Prawo do życia ma wymiar fundamentalny dla wszystkich innych, wyrastających z niego uprawnień, które do swej realizacji wymagają podmiotu, któremu mogłyby przysługiwać. Człowiek nabywa je z chwilą pierwszego zarysowania swojej obecności na tym świecie, a więc z chwilą poczęcia. Ochrona tego prawa to jedno z najważniejszych zadań państwa. Tylko wtedy możemy mówić o reprezentowaniu przez kraj jakiegokolwiek zespołu wartości. Jeżeli wartość nadrzędna, jaką jest życie ludzkie, zostanie zakwestionowana i nie będzie w sposób należyty chroniona prawnie, to zakwestionowanie każdej innej wartości, będzie już tylko konsekwencją tego precedensu. Jeżeli uświadomimy sobie aksjologiczne znaczenie życia ludzkiego, to z całą zgrozą należy skierować uwagę na prawodawstwo wielu dzisiejszych państw. Prawo do życia wydaje się mieć tam charakter ekskluzywny i przysługiwać tylko wybranym. Człowiek, przez pewien krótszy, dłuższy albo nawet cały - okres rozwoju prenatalnego pozbawiony został prawnej ochrony życia. Władza państwowa przyznała sobie kompetencje do dystrybuowania człowieczeństwa. Pomimo że, zważając na różnice światopoglądowe, nie możemy z absolutną pewnością, akceptowalną dla wszystkich, stwierdzić

${ }^{5}$ Leon XIII, enc. Libertas praestantissimum, [w:] Katechizm Kościoła Katolickiego (dalej: KKK) 1954.

${ }^{6}$ KKK 1956. 
kto/co jest źródłem człowieczeństwa, to wydaje się, że z dużą dozą pewności możemy stwierdzić, że źródłem tym nie jest władza państwowa. Jeżeli bowiem założyć, że aparat państwa jest dawcą naszego człowieczeństwa, należałoby konsekwentnie przyjąć, że może on również nam je w sposób dowolny ograniczyć lub nawet odebrać. Takie podejście stanowi prostą drogę do najbardziej nieludzkich totalitaryzmów. Należy więc sprzeciwiać mu się z całą mocą, co wielokrotnie czynił Jan Paweł II.

W encyklice Evangelium vitae papież podkreślał, że:

Chodzi tu zresztą o sprawę tak wielką z punktu widzenia powinności moralnej, że nawet samo prawdopodobieństwo istnienia osoby wystarczyłoby dla usprawiedliwienia najbardziej kategorycznego zakazu wszelkich interwencji zmierzających do zabicia embrionu ludzkiego (...). Istota ludzka powinna być szanowana i traktowana jako osoba od momentu swego poczęcia i dlatego od tego samego momentu należy jej przyznać prawa osoby, wśród których przede wszystkim nienaruszalne prawo każdej niewinnej istoty ludzkiej do życia. ${ }^{7}$

Jeżeli prawo do życia, na każdym etapie rozwoju człowieka (również prenatalnym!), nie zostanie należycie zagwarantowane, to dyskusja nad pozostałymi prawami, wydaje się tracić sens.

\section{Wolność}

Zacznijmy od definicji. Wolność człowieka oznacza „jego naturalną zdolność do podejmowania aktów woli (decyzji) i ich realizacji, która w warunkach życia jednostki w społeczeństwie podlega ograniczeniom, w celu zapewnienia innym takiej samej możliwości korzystania z wolności”8. Z idei wolności wyrastają konkretne kategorie wolności osobiste, polityczne, społeczne, ekonomiczne i kulturalne. Każda z nich znajduje swoje urzeczywistnienie z zapisach konstytucyjnych (w Konstytucji Rzeczypospolitej Polskiej w Rozdziale II). Jednak doświadczenie historyczne uczy, że im więcej mówi się o wolności w aktach prawnych, tym mniej jest jej w życiu. Ustrojem, który werbalnie z największym pietyzmem traktował wolność był komunizm. Konstytucja Związku Socjalistycznych Republik Radzieckich zawierała największy, jak na swoje czasy, katalog praw i wolności, włącznie z prawem obywatela do przemieszczania się za pomocą metra.

\footnotetext{
${ }^{7}$ Jan Paweł II, enc. Evangelium vitae, 60.

${ }^{8} \mathrm{~L}$. Wiśniewski, Wolności i prawa jednostki oraz ich gwarancje w praktyce, Warszawa 2006 [w:] Leksykon wspótczesnej teorii..., dz. cyt.
} 
Problem zawsze stwarza określenie relacji pomiędzy ludzką wolnością a państwem. Stosunek ten trzeba wyważyć w taki sposób, aby z jednej strony zbyt daleko posunięta i źle rozumiana wolność obywateli nie zniszczyła państwa, z drugiej - aby władza państwowa nie stała się względem jednostek omnipotencyjna i nie wchłonęła ich wolności. Takie dwie skrajne postawy odnaleźć można w liberalizmie i komunizmie.

Pierwszy dąży do zbudowania państwa minimum. Udział aparatu państwa w życiu jednostek sprowadzałby się do wykonywania zadań, na które państwo ze swej istoty - musi mieć monopol. Wymienia się tutaj przede wszystkim zapewnienie wewnętrznego i zewnętrznego bezpieczeństwa państwa, minimalną infrastrukturę administracyjną, prowadzenie polityki zagranicznej. Poza tym, wszelki interwencjonizm państwowy jest w liberalizmie postrzegany jako przekroczenie przez organy publiczne ich kompetencji. Sprawy pomiędzy obywatelami powinny być załatwiane przez nich samych, według uznania ich woli, wyrażonej w umowach cywilno-prawnych. Gospodarka opiera się na własności prywatnej i zindywidualizowanej wolności. Co więcej, reguluje się ją w oparciu o zasady wolnego rynku, zaś wszelkie programy socjalne uznawane są za niepotrzebne działanie za strony państwa.

Komunizm, oparty na filozofii marksistowskiej, chce zbudować państwo wszechwładne. Pomimo reklamowania władzy komunistycznej jako władzy ludu, władztwo pojedynczego człowieka - nawet nad samym sobą - postrzegane jest jako zło, które trzeba zlikwidować. W ustroju komunistycznym jednostkę postrzega się jako część społeczeństwa, które z kolei utożsamia się z państwem. Człowiek zostaje więc tam pozbawiony swojej indywidualności. Wolność ludzka ma służyć wszystkim, a wszyscy to państwo. Własność rozumie się kolektywnie, gospodarka nie dopuszcza własności prywatnej, opierając się na przekonaniu, że wszystko jest dobrem wspólnym. W tym miejscu pojawia się pytanie - kto powinien nim zarządzać? Oczywiście wszyscy, czyli państwo. W systemach komunistycznych występuje reglamentacja dóbr przez państwo. Gospodarka jest scentralizowana i regulowana przez państwo. W zamian państwo bierze na siebie odpowiedzialność za człowieka. Narzuca mu reguły, według których musi postępować i - na swój sposób - pomaga mu w ich przestrzeganiu. Aktywność socjalna państwa jest duża, bowiem tylko ono ma możliwości udzielania obywatelom jakiegokolwiek wsparcia, gdyż wszystko do niego należy.

Wnikliwą krytykę obydwu tych systemów przeprowadził Jan Paweł II. W liberalizmie przeciwstawiał się istnieniu dzikiego kapitalizmu, w którym zysk i kapitał stanowiłyby usprawiedliwienie dla nieposzanowania ludzkiej godności. Pisał papież: 
Niewątpliwie istnieje sfera uzasadnionej autonomii gospodarki, w którą państwo nie powinno ingerować. Ma ono jednak obowiązek określania ram prawnych, wewnątrz których rozwijają się relacje gospodarcze, i w ten sposób stworzenia podstawowych warunków wolnej ekonomii, która zakłada pewną równość pomiędzy stronami, tak że jedna z nich nie może być na tyle silniejsza od drugiej, by ją praktycznie zniewolić. ${ }^{9}$

Papież postrzegał socjalizm jako system oparty na niewłaściwych wartościach i dlatego niemogący wydać dobrych owoców:

Podstawowy błąd socjalizmu ma charakter antropologiczny. System socjalistyczny ujmuje pojedynczego człowieka jako zwykły element i cząstkę organizmu społecznego, tak że dobro jednostki zostaje całkowicie podporządkowane działaniu mechanizmu ekonomiczno-społecznego; z drugiej strony doktryna socjalizmu zakłada, że dobro jednostki można urzeczywistnić nie uwzględniając jej samodzielnego wyboru i niezależnie od przyjęcia przez nią w sposób indywidualny i wyłączny odpowiedzialności za dobro czy zło. (...) Skutkiem tej błędnej koncepcji osoby jest deformacja prawa, określająca zakres wolności człowieka, a także sprzeciw wobec własności prywatnej. Człowiek pozbawiony wszystkiego co mógłby „nazwać swoim” oraz możliwości zarabiania na życie dzięki własnej przedsiębiorczości, staje się zależny od machiny społecznej i od tych, którzy sprawują nad nią kontrolę, co utrudnia mu znacznie rozumienie swej godności jako osoby i zamyka drogę do tworzenia autentycznej ludzkiej wspólnoty. ${ }^{10}$

Wskazując właściwe rozwiązania ustrojowe, Jan Paweł II proponował oparcie gospodarki na wolnym rynku, który „jest najbardziej skutecznym narzędziem wykorzystywania zasobów i zaspokajania potrzeb”. Działanie państwa powinno być oparte na zasadzie subsydiarności i solidarności. Należy stworzyć warunki dla „procesu samoorganizowania się społeczeństwa"11, które będzie mogło, jako wspólnota, pomóc najbardziej potrzebującym. Państwo powinno stworzyć ku temu odpowiednią infrastrukturę, a jeżeli działania obywatelskie okażą się niewystarczające, interweniować bezpośrednio. Papież podkreślał konieczność poszanowania ludzkiej wolności:

Lekceważenie natury człowieka, stworzonego dla wolności, jest nie tylko niedozwolone z punktu widzenia etycznego, ale i praktycznie niemożliwe. Gdzie or-

\footnotetext{
${ }^{9}$ Jan Paweł II, enc. Centesimus Annus, 15.

${ }^{10}$ Jan Paweł II, enc. Centesimus Annus, 13.

${ }^{11}$ Jan Paweł II, enc. Centesimus Annus, 16.
} 
ganizacja społeczeństwa ogranicza czy wręcz eliminuje sferę wolności przysługującej obywatelom, tam życie ulega stopniowemu rozkładowi i zamiera ${ }^{12}$.

Jan Paweł II przestrzegał też jednocześnie przed źle pojętą wolnością, która w warunkach wolnorynkowych, może prowadzić do wyzysku i niesprawiedliwości. Dlatego nasza wolność powinna zostać „zakorzeniona w prawdzie człowieka i skierowana ku wspólnocie"13. Takim ustrojem może być, zdaniem Jana Pawła II, kapitalizm rozumiany jako „system ekonomiczny, który uznaje zasadniczą oraz pozytywną rolę przedsiębiorstwa, rynku, własności prywatnej i wynikającej z niej odpowiedzialności za środki produkcji oraz wolnej ludzkiej inicjatywy w dziedzinie gospodarczej” ${ }^{14}$, który nakierowany jest na stworzenie „społeczeństwa godnego człowieka"15.

Współcześnie wiele zastrzeżeń $\mathrm{w}$ dziedzinie gwarancji dla wolności budzą: przymusowy system - często nierentownych i nieefektywnych - ubezpieczeń społecznych, koncesjonowanie wybranych gałęzi gospodarki, przytłaczająca ilość niejasnych regulacji podatkowych i skarbowych, hamujących przedsiębiorczość i stwarzających możliwość ekonomicznej opresji ze strony państwa, a także nadużycia bądź ograniczenia wolności słowa w Internecie.

\section{Własność}

Własność definiuje się jako zdolność do wytwarzania bogactwa i zarządzania nim. W filozofii występują poglądy, głoszące że własność jest konsekwencją wolności (takiego zdania był na przykład Immanuel Kant). Pogląd ten (bez zagłębiania się w szczegółowe przemyślenia filozofa) wydaje się uzasadniony i wskazuje na nierozerwalność wolności i własności. Podobna koncepcja obecna jest w doktrynie Kościoła Katolickiego. W konstytucji duszpasterskiej o Kościele w świecie współczesnym Gaudium et spes, którą w swojej encyklice Centesimus Annus przytaczał Jan Paweł II, czytamy:

Własność prywatna lub pewne dysponowanie dobrami zewnętrznymi dają każdemu przestrzeń koniecznie potrzebną dla autonomii osobistej i rodzinnej, i należy je uważać za poszerzenie niejako wolności ludzkiej. ${ }^{16}$

\footnotetext{
${ }^{12}$ Jan Paweł II, enc. Centesimus Annus, 25.

${ }^{13}$ Jan Paweł II, enc. Veritatis Splendor, 86.

${ }^{14}$ Jan Paweł II, enc. Centesimus Annus, 42.

${ }^{15}$ Jan Paweł II, enc. Centesimus Annus, 25.

${ }^{16}$ Konstytucja Gaudium et spes, 69-71, [w:] Jan Paweł II, enc. Centesimus Annus, 30.
} 
Warto zaznaczyć, że mowa jest tutaj o własności prywatnej. Taką własność papież Leon XIII uznał za prawo naturalne ${ }^{17}$. Przedefiniowanie własności (oraz wolności) na modłę kolektywizmu zostało dokonane przez komunistów i zaowocowało jednym $z$ najgorszych totalitaryzmów w historii świata. Własność prywatna, zagwarantowana prawnie jest charakterystyczna dla ustrojów kapitalistycznych.

Pojęcie własności łączy się nierozerwalnie z pracą i przedsiębiorczością. Stanowi ona, wspólnie z wolnością, podstawowe źródło bogactwa. Przytoczmy w tym miejscu dłuższy fragment z encykliki Centesimus Annus:

Jeżeli ktoś wytwarza jakiś przedmiot, to czyni to na ogół nie tylko dla własnego użytku, ale także po to, by inni mogli go używać po zapłaceniu słusznej ceny, ustalonej za wspólną zgodą w drodze wolnej umowy. Otóż właśnie zdolność rozpoznawania najbardziej odpowiednich w porę potrzeb innych ludzi oraz układów czynników produkcyjnych najbardziej odpowiednich do ich zaspokojenia jest kolejnym ważnym źródłem bogactwa współczesnego społeczeństwa. Istnieje zresztą wiele dóbr, których nie można w odpowiedni sposób wytworzyć pracą jednego człowieka i które wymagają zmierzającej do jednego celu współpracy wielu osób. Zorganizowanie takiego wysiłku, rozplanowanie go w czasie, zatroszczenie się, by rzeczywiście odpowiadał temu, czemu ma służyć, oraz podjęcie koniecznego ryzyka, jest dziś także źródłem bogactwa społeczeństwa. W ten sposób staje się coraz bardziej oczywista i determinująca rola zdyscyplinowanej i kreatywnej pracy ludzkiej oraz - jako istotna część tej pracy - rola zdolności do inicjatywy i przedsiębiorczości. ${ }^{18}$

Zaznaczyłem w poprzednim akapicie, że praca to immanentna część własności. zatem konsekwencją tego stwierdzenia jest pytanie o to, czym jest praca? Otóż, stanowi ona jeden z trzech (obok ziemi i kapitału) czynników produkcji. W ekonomii pod pojęciem tym rozumiemy fizyczną zdolność człowieka do wykonywania określonych czynności wraz z jego motywacjami i kwalifikacjami ${ }^{19}$.

Gdy mowa jest o własności, nie sposób nie podjąć tematu pracy.

Do wytwarzania bogactwa często potrzeba współpracujących ze sobą wielu osób, zorganizowanych w jednostkę gospodarczą (czyli w przedsiębiorstwo). Zasadniczym celem przedsiębiorstwa jest produkcja dóbr lub usług, a następnie obracanie nimi na rynku, w celu generowania zysku. Widzimy więc, że ostateczny cel funkcjonowania przedsiębiorstw stanowi zysk. W tym momencie rodzi się zagrożenie, że nasza własność stanie się źródłem egoizmu i chciwości wymierzo-

\footnotetext{
${ }^{17}$ Enc. Rerum Novarum s. 99-107; 131-133, [w:] Jan Paweł II, enc. Centesimus Annus, 30.

${ }^{18}$ Jan Paweł II, enc. Centesimus Annus, 32.

${ }^{19}$ Praca, https://encyklopedia.pwn.pl/haslo/praca; 3961600.html (18.09.2018).
} 
nych w innych. Dlatego tak ważne jest, aby to przyrodzone prawo rozeznawać w duchu miłości bliźniego:

Kościół uznaje pozytywną rolę zysku jako wskaźnika dobrego funkcjonowania przedsiębiorstwa: gdy przedsiębiorstwo wytwarza zysk, oznacza to, że czynniki produkcyjne zostały właściwie zastosowane, a odpowiadające im potrzeby ludzkie - zaspokojone. Jednakże zysk nie jest jedynym wskaźnikiem dobrego funkcjonowania przedsiębiorstwa. Może się zdarzyć, że mimo poprawnego rachunku ekonomicznego ludzie, którzy stanowią najcenniejszy majątek przedsiębiorstwa, są poniżani i obraża się ich godność. Jest to nie tylko moralnie niedopuszczalne, lecz na dłuższą metę musi też negatywnie odbić się na gospodarczej skuteczności przedsiębiorstwa. Celem zaś przedsiębiorstwa nie jest po prostu wytwarzanie zysku, ale samo jego istnienie jako wspólnoty ludzi, którzy w różny sposób zdążają do zaspokojenia swych podstawowych potrzeb i stanowią szczególną grupę służącą całemu społeczeństwu. ${ }^{20}$

Nie ulega wątpliwości, że w zarządzaniu przedsiębiorstwem wymagane są dobrze ukształtowana wrażliwość i moralność. Jak je zapewnić i jaka jest w tym rola państwa?

\section{Państwo opiekuńcze}

Zacznijmy tym razem nie od definicji, ale od pewnego sprostowania. Państwo opiekuńcze to termin specyficzny dla naszego języka. Oryginalnie termin pochodzi z języka angielskiego (welfare state) i oznacza państwo dobrobytu. Państwo opiekuńcze jest nazwą zwodniczą, ponieważ opieka kojarzy się w naszej kulturze z czymś dobrym i szlachetnym. Wydaje się, że bardziej adekwatne byłoby tutaj mówienie o państwie nadopiekuńczym. O tym, dlaczego proponuję taką nazwę, opowiem za chwilę.

Po wstępnych wyjaśnieniach możemy przejść do definicji. Dr hab. Ryszard Szarfenberg proponuje następującą interpretację pojęcia państwa opiekuńczego:

Państwo (administracja rządowa i samorządowa) angażujące się nie tylko w sprawy opieki i pomocy społecznej, ale też w szeroki zakres spraw dotyczących dobrobytu obywateli i mieszkańców. Mające na względzie przede wszystkim wartości takie jak równość i bezpieczeństwo w wymiarze ekonomicznym, które po przełożeniu na kon-

\footnotetext{
${ }^{20}$ Jan Paweł II, enc. Centesimus Annus, 35.
} 
kretne cele stara się osiągać poprzez różnorodne instrumenty oddziaływania pośredniego i bezpośredniego na zachowania ludzi oraz warunki ich życia ${ }^{21}$.

Przy pierwszym wrażeniu taka definicja zdaje się interesująca i może stwarzać pozory zgodnej ze społeczną nauką Kościoła Katolickiego. Nic bardziej mylnego.

Państwo opiekuńcze w swoich założeniach zbliża się do koncepcji państwa maksimum, czyli do socjalizmu ${ }^{22}$. Krótszą definicją, często spotykaną w literaturze, jest opis państwa opiekuńczego jako takiego, które dąży do likwidacji ubóstwa. Warto się nad tym zatrzymać. Państwo chce likwidować ubóstwo. Nie chce jednak maksymalizować bogactwa. Dąży do równości w sferze ekonomicznej, ale równość nie oznacza, że sytuacja ekonomiczna wszystkich będzie równie dobra. Może być równie średnia. Państwo (nad)opiekuńcze dąży do przejęcia - w jak najszerszym zakresie - odpowiedzialności za dobro jednostki, która do tej pory spoczywała przede wszystkim na niej samej pojedynczej osobie. Odgórne narzucanie gotowych rozwiązań społeczeństwu, pod płaszczykiem troski o ich dobro i równość, ogranicza ludzką wolność i naturalną różnorodność. Dąży do uzależnienia jednostki od państwa, zwłaszcza na płaszczyźnie ekonomicznej. Zmniejszanie poziomu ubóstwa poprzez bezpośredni interwencjonizm państwowy, może podcinać skrzydła jednostkom najbardziej uzdolnionym i przedsiębiorczym. Próba szczegółowej regulacji każdej sfery życia obywateli zawsze prowadzi do rozrostu na nienaturalną skalę - biurokracji państwowej oraz utworzenia bardzo skomplikowanego systemu prawnego. Ponadto, takie państwo może narzucać obywatelom swoje własne wartości nawet wbrew ich woli. Na przykład darmowa ochrona zdrowia (opłacana przez wszystkich obywateli w przymusowych składkach) będzie refundowała zabiegi aborcyjne. Taki człowiek, może doświadczyć konfliktu wewnętrznego, bo musi finansować coś, co uważa za moralnie niedopuszczalne.

O państwie opiekuńczym pisał również Jan Paweł II:

Niesprawności i niedostatki w państwie opiekuńczym wynikają z nieodpowiedniego rozumienia właściwych państwu zadań. Także w tej dziedzinie winna być przestrzegana zasada pomocniczości, która głosi, że społeczność wyższego rzędu nie powinna ingerować w wewnętrzne sprawy społeczności niższego rzędu, pozbawiając ją kompetencji, lecz raczej winna wspierać ją w razie konieczności i pomóc w koordynacji jej działań z działaniami innych grup społecznych, dla dobra wspólnego. Interweniując bezpośrednio i pozbawiając społeczeństwo odpowiedzialności, państwo opiekuńcze powoduje utratę ludzkich energii i przesadny wzrost publicznych struktur, w których -

${ }^{21}$ http://rszarf.ips.uw.edu.pl/pdf/panstwo_opiekuncze.pdf (18.09.2018).

${ }^{22} \mathrm{http} / / /$ rszarf.ips.uw.edu.pl/pdf/panstwo_opiekuncze.pdf (18.09.2018), s. 3. 
przy ogromnych kosztach - raczej dominuje logika biurokratyczna, aniżeli troska o to, by służyć korzystającym z nich ludziom. ${ }^{23}$

Państwo (nad)opiekuńcze ingeruje zarówno w ludzką wolność, własność a może również nawet życie. Jest to model państwa, który angielski filozof Thomas Hobbes, określił mianem Lewiatana.

\section{Podsumowanie}

Wzór państwa, wyłaniający się z katolickiej nauki społecznej, musi partycypować w takich wartościach jak życie, wolność i własność. Wydaje się, że tak jak państwo opiekuńcze bliższe jest koncepcji państwa maksimum, tak - nawiązując do św. Augustyna - „państwo Boże” jest bliżej państwa minimum. Oczywiście, należy zaznaczyć, że państwo musi posiadać pewne kompetencje i umieć z nich korzystać, jednak wszystkie te działania powinny opierać się poszanowaniu zasady pomocniczości oraz zasady solidarności.

Powtórzę w tym miejscu jeszcze raz, to co już zostało napisane na początku tych rozważań.

Niepodległość nie jest celem samym w sobie. Jest narzędziem, celem jest wolność.

\section{Abstract \\ What's the point of country's existence?}

What's the aim of well-working country? Independence in itself it's not the aim. Independence is only beginning of the long way. Nation has to be built on a strong axiological base. After I had delved into works of John Paul II, I came to conclusion that this axiological base must be natural law. Limiting to minimum, I chose three the most major values - life, freedom and property. Thanks to them we can conclude the most important founding rules of the human world.

Keywords: independence, life, freedom, property, John Paul II

\footnotetext{
${ }^{23}$ Jan Paweł II, enc. Contesimus Annus 48.
} 
4. Uniwersytet Papieski

Pfog Jana Pawła II 